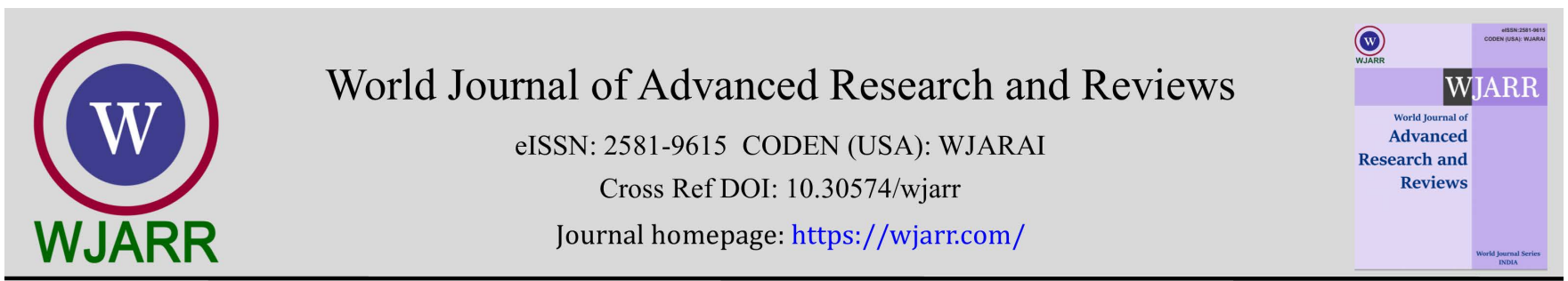

(RESEARCH ARTICLE)

\title{
Investigation of heavy metal levels of clams (Egeria radiata) sold in open markets in Port Harcourt and Yenagoa, Nigeria
}

\author{
Benjamin Uchechukwu Nti 1, Okechukwu Kenneth Wokeh 2,* and Chidinma Georginia Okey-Wokeh 3 \\ ${ }^{1}$ Department of Biology, Federal University of Technology, PMB 1526, Owerri. Nigeria. \\ 2 Department of Animal and Environmental Biology, University of Port Harcourt, PMB 5323, Port Harcourt, Nigeria. \\ 3 Department of Chemistry, Rivers State University, Port Harcourt, PMB 5080, Nkpolu-Orowurukwo, Nigeria.
}

World Journal of Advanced Research and Reviews, 2021, 11(03), 109-114

Publication history: Received on 03 August 2021; revised on 08 September 2021; accepted on 10 September 2021

Article DOI: https://doi.org/10.30574/wjarr.2021.11.3.0426

\begin{abstract}
Due to rapid urbanization, increase in coastal population, oil and gas exploration and other array of anthropogenic activities within the Niger Delta region of which Rivers and Bayelsa states are prominent amongst others, the region has been faced with coastal water pollution. There is need therefore, to evaluate the intensity of environmental contamination of the aquatic ecosystem in this region, thus this study was conducted to investigate the heavy metal levels of Clams (Egeria radiata) sold in open markets in Port Harcourt (Rivers State) and Yenagoa (Bayelsa State). Samples were collected from three markets in Port Harcourt (Mile 1, Rumuokoro and Mile 3), and three markets as well in Yenagoa (Opolo, Swali and Tombia) respectively. The samples were collected bi-weekly for 3 months and transported to the laboratory for analysis of heavy metals $(\mathrm{Cr}, \mathrm{Cd}$ and $\mathrm{Pb}$ ) levels using standard scientific method of analysis. The analysis was done in triplicates for each sample and data obtained were subjected to statistical analysis using excel spreadsheet and statistical package for social sciences (SPSS) version 21. The results revealed that samples collected from markets in Port Harcourt had higher concentrations of heavy metal than that of Yenagoa, though, the heavy metal levels were below World Health Organisation permissible limits, except for Cadmium (Cd) that ranged from $0.54 \pm 0.002$ to $0.78 \pm 0.00 \mathrm{mg} / \mathrm{kg}$ in samples collected from Port Harcourt, against $0.5 \mathrm{mg} / \mathrm{kg}$ recommended by WHO. This could be attributed to oil and gas exploration, and discharges of industrial and domestic wastes bearing cadmium, and poses serious health risks. Therefore, routine monitoring and assessment of the aquatic ecosystem will be vital to forestall further contamination.
\end{abstract}

Keywords: Analysis; Clams; Heavy Metals; Market; Niger Delta

\section{Introduction}

Over the years, water pollution has become one of the major environmental challenges facing most of the states in Southern Nigeria, particularly the Niger Delta region. Niger Delta is one of the most prominent regions in Nigeria with vast aquatic ecosystems greatly blessed with variety of fish species both Fin and Shell fishes [1]. Amongst other states in the region, Rivers and Bayelsa State coastal waters are faced with massive environmental pollutions due to increased coastal population, rapid urbanization, oil and gas explorations, heavy rainfall throughout the year and other array of anthropogenic activities which are capable of deteriorating the aquatic ecosystem [2, 3]. Most of these activities generate wastes that bear heavy metals that cause environmental degradation and oftentimes, these heavy metals which are non-biodegradable, accumulate in organs and tissues of aquatic organisms like Clams, Oysters and Cockles through their diets and respiration, thereby posing a serious health risk to human and other animals when consumed [4].Therefore, it is important to evaluate the levels of heavy metals in shellfishes like Clam, sold in major open markets in Port Harcourt and Yenagoa because of anthropogenic activities prominent in these areas.

\footnotetext{
* Corresponding author: Okechukwu Kenneth Wokeh

Department of Animal and Environmental Biology, University of Port Harcourt, PMB 5323, Port Harcourt, Nigeria. 
Heavy metals are known as metallic elements that have a relatively high density compared to water, and they include Cadmium (Cd), Chromium (Cr), Lead (Pb), Nickel (Ni), Zinc (Zn) and other potentially hazardous elemental forms [5]. The environmental impacts of heavy metals have become a subject of public concern as a result of their hard consequences [6]. Globally, heavy metals are known for their toxicity, non-biodegradability, bioaccumulation tendency and persistency in the ecosystem [7]. All these put together, make the metals dangerous, hence their toxins contribute to a variety of adverse health effects [8], and unfortunately, fish food is one main channel through which heavy metals enters into human body [9].

Fish is one major source of food protein of animal origin for the population across the globe, providing both saturated and unsaturated fatty acids, liposoluble vitamins and essential minerals which are associated with health benefits and normal growth $[10,11]$. Freshwater Clam has been one edible shellfish that is essential to man and widely eaten for its proteineous and mineral content [12]. Egeria radiata are found around the mangrove swamp mudflats and are known as accumulator of heavy metals, which have been widely used as bio-indicator for monitoring and evaluating pollution in aquatic ecosystem $[13,3]$.

It is against this backdrop that the study on investigation of heavy metal levels of Clams sold in open markets in Port Harcourt and Yenagoa was conducted, as results obtained from the study will serve as baseline information for researchers, health experts and regulatory agencies.

\section{Material and methods}

\subsection{Description of Study Area}

The study was carried out in two contiguous states of Rivers and Bayelsa as shown in Fig. 1 \& 2

\subsubsection{Location 1: Port Harcourt}

Port Harcourt is one of the largest cities in the Niger Delta region, serving as the administrative capital of Rivers State (see Fig 1). It is a hub of both industrial and commercial activities in southern Nigeria with prominent oil and gas companies operating in many parts of the city. The city of Port Harcourt plays host to the popular Rumuokoro, Mile 1

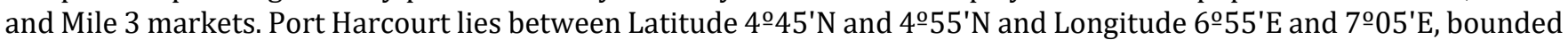
in the North by Imo and Abia States, in the East by Akwa-Ibom state, in the West by Bayelsa state and in the South by the Atlantic Ocean[14]. It has an estimated population of over 1,865000 inhabitants.

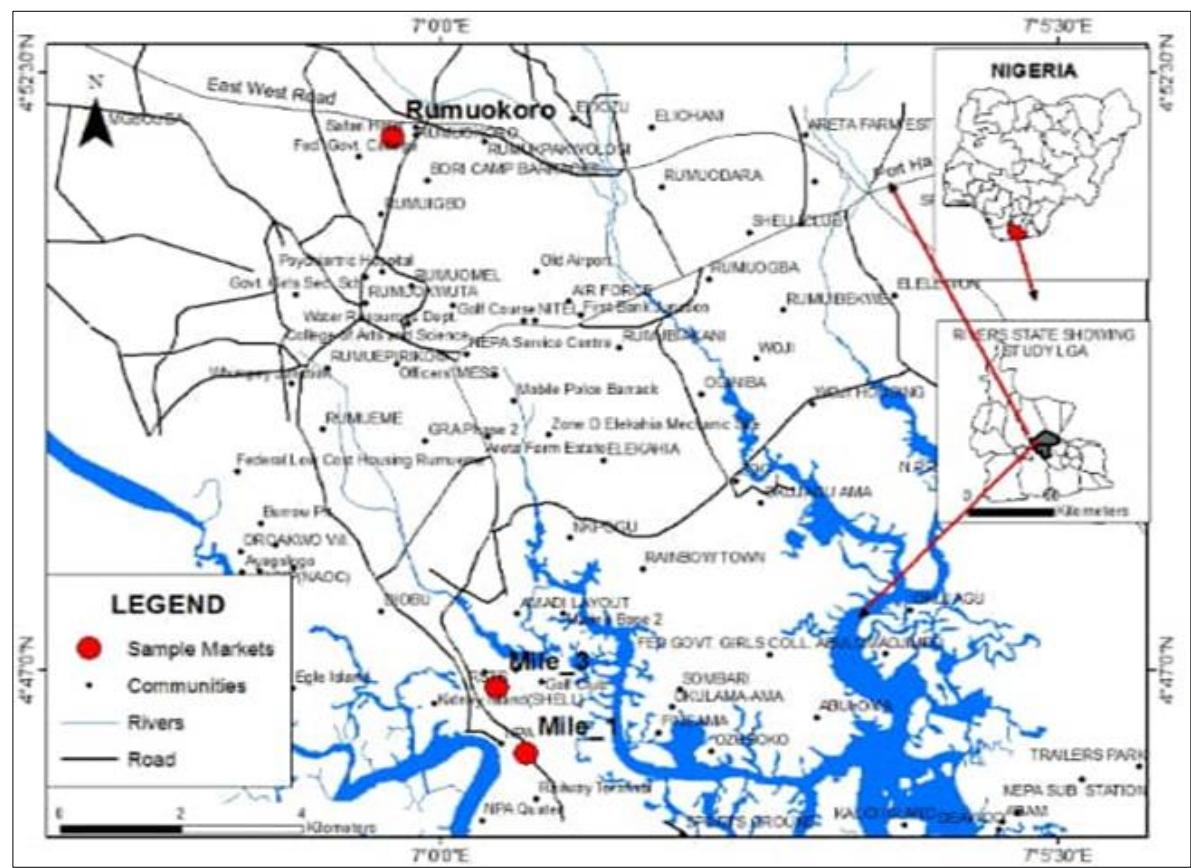

Figure 1 Map of Port Harcourt Showing the Sample Sites 


\subsubsection{Location 2: Yenagoa}

Yenagoa was the second location for this study. It is the administrative capital of Bayelsa state and it lies between Latitude $4^{\circ} 55^{\prime} \mathrm{N}$ and Longitude $6^{\circ}{ }^{\circ} 5^{\prime} \mathrm{E}$. The city of Yenagoa is known for the array of anthropogenic activities such as oil exploration, sand dredging, artisanal fishing and mechanic shops, abattoir businesses and others marketing activities. It has a total land mass of $706 \mathrm{~km}^{2}$, with a population estimated to be over 352,282. Yenagoa plays host to the popular Tombia, Swali and Opolo markets as shown in Fig. 2.

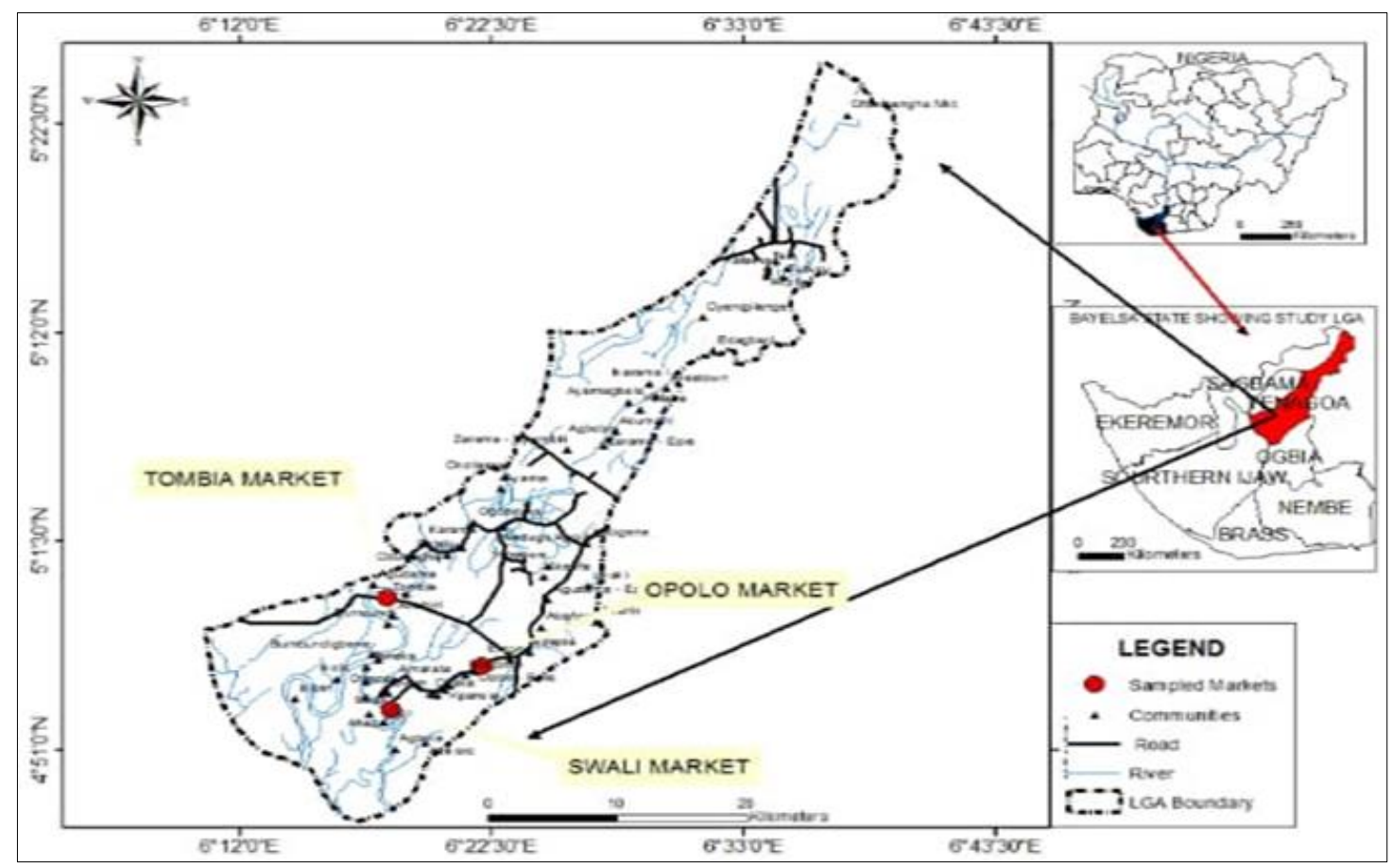

Figure 2 Map of Study Area Showing Sampled Markets in Yenagoa

\subsection{Sample Collection}

Samples of Clams (see Fig. 3) were collected from three open markets in Port Harcourt, Rivers State and Yenagoa, Bayelsa State. The samples were collected bi-weekly for the period of three months at Mile 1 market and coded as (PM 1), Rumuokoro market (PM 2) and Mile 3 market as (PM 3) for easy identification. The samples of clams collected from open markets in Yenagoa were obtained from Opolo market and coded as (YM 1), Swali market (YM 2) and Tombia market as (YM 3). The dried samples procured from each of these markets were kept in isolated containers and then transported to the laboratory for analysis.
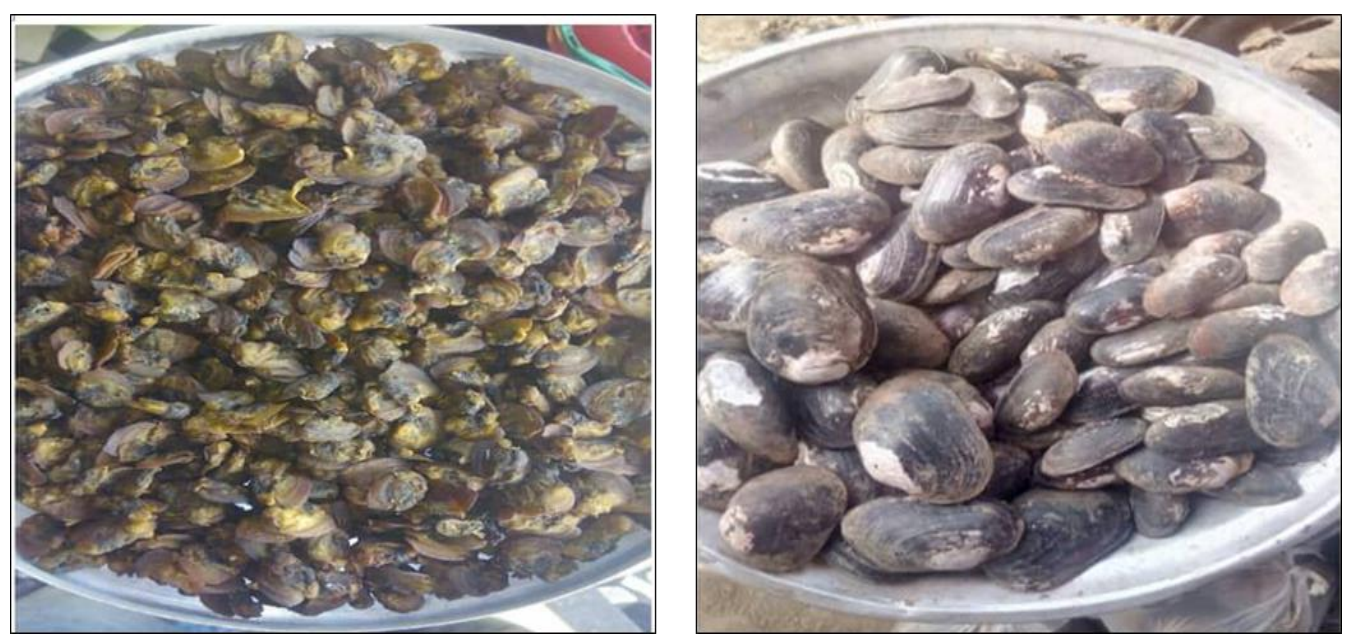

Figure 3 Samples of Clams 


\subsection{Sample Analysis}

Samples of freshwater Clams collected were placed in a folded aluminum foil and dried in an air-circulating oven for 3 to 4 days at a temperature above $50^{\circ} \mathrm{C}$ until a dry weight was achieved before metal analysis. The entire dried samples of Clams were then used for acid digestion. For digestion, the dried powdered samples were measured in a $50 \mathrm{ml}$ tube then transferred to $250 \mathrm{ml}$ conical flask, thereafter, $3 \mathrm{ml}$ of concentrated acid was added to the sample in the flask and transferred to the digestion tube where it was heated for about 15-20 minutes for the hot plate to bring the metals into solution. The digestion was stopped and cooled, and after cooling, the solution was sieved using a Whatman 42 filter paper in a $50 \mathrm{ml}$ volumetric flask. Distilled water was added to make mark and it was then conveyed to a $100 \mathrm{ml}$ Can for heavy metal $(\mathrm{Cr}, \mathrm{Cd}$ and $\mathrm{Pb})$ analysis using flame atomic absorption spectrophotometer(AAS), Perkin-Elmer Analyst 300.All the samples obtained from each site, were analyzed in triplicates for accurate result.

\subsection{Statistical analysis}

The statistical data were analyzed using one-way analysis of variance with the aid of computer software (Microsoft Excel and SPSS version 21).

\section{Results and discussion}

The results of heavy metal concentrations of samples collected from open markets in Port Harcourt and Yenagoa, are shown in Table 1

Table 1 Results of Heavy Metals in Clams Sampled from Markets in Port Harcourt and Yenagoa

\begin{tabular}{|l|c|c|c|}
\hline Markets & Cr (mg/kg) & Cd (mg/kg) & Pb (mg/kg) \\
\hline Mile 1 (PM 1) & $0.066 \pm 0.001$ & $0.78 \pm 0.001$ & $0.77 \pm 0.003$ \\
\hline Rumuokoro (PM 2) & $0.080 \pm 0.004$ & $0.54 \pm 0.002$ & $0.081 \pm 0.001$ \\
\hline Mile 3 (PM 3) & $0.036 \pm 0.006$ & $0.61 \pm 0.00$ & $0.078 \pm 0.023$ \\
\hline Opolo (YM 1) & $0.040 \pm 0.001$ & $0.032 \pm 0.002$ & $0.036 \pm 0.001$ \\
\hline Swali (YM 2) & $0.043 \pm 0.003$ & $0.035 \pm 0.00$ & $0.041 \pm 0.010$ \\
\hline Tombia (YM 3) & $0.041 \pm 0.02$ & $0.044 \pm 0.001$ & $0.040 \pm 0.020$ \\
\hline
\end{tabular}

Table 2 WHO Permissible Limits of Heavy Metals for Human Consumption

\begin{tabular}{|l|c|}
\hline Parameters & WHO Standard \\
\hline $\mathrm{Cr}(\mathrm{mg} / \mathrm{kg})$ & 13.0 \\
\hline $\mathrm{Cd}(\mathrm{mg} / \mathrm{kg})$ & 0.5 \\
\hline $\mathrm{Pb}(\mathrm{mg} / \mathrm{kg})$ & 1.5 \\
\hline
\end{tabular}

The samples of Clams from Mile 1 market (PM1) contained all the tested heavy metals in the increasing order of $\mathrm{Cr}, \mathrm{Pb}$ and Cd ranging from $0.066 \pm 0.001 \mathrm{mg} / \mathrm{kg}$ to $0.78 \pm 0.000$.The samples of Clams collected from Rumuokoro market (PM2) also contained all the tested heavy metals; $\mathrm{Cd}, \mathrm{Cr}$ and $\mathrm{Pb}$ in the following increasing order: $\mathrm{Cr}, \mathrm{Pb}$ and $\mathrm{Cd}$, ranging from $0.080 \pm 0.004 \mathrm{mg} / \mathrm{kg}$ to $0.54 \pm 0.0002 \mathrm{mg} / \mathrm{kg}$. The results of heavy metals in samples obtained from Mile 3 market (PM3), showed that all the tested metals were present in the following increasing order, $\mathrm{Cr}, \mathrm{Pb}$ and $\mathrm{Cd}$ ranging from $0.036 \pm 0.006$ to $0.61 \pm 0.00 \mathrm{mg} / \mathrm{kg}$. The results of heavy metal concentrations in samples collected from markets in Yenagoa, showed that samples procured from Opolo market (YM1) contained all the tested metals in the following increasing order; $\mathrm{Cd}, \mathrm{Pb}$ and $\mathrm{Cr}$, ranging from $0.032 \pm 0.002 \mathrm{Mg} / \mathrm{Kg}$ to $0.040 \pm 0.001 \mathrm{mg} / \mathrm{kg}$. Also, the results of samples collected from Swali market (YM2), showed that all the tested heavy metals were present in the increasing order of Cd, $\mathrm{Pb}$ and $\mathrm{Cr}$ ranging from $0.035 \pm 0.00 \mathrm{Mg} / \mathrm{Kg}$ to $0.043 \pm 0.003 \mathrm{mg} / \mathrm{kg}$. Samples procured from Tombia market (YM3), showed that all the tested heavy metals were present in the following increasing order; $\mathrm{Pb}, \mathrm{Cr}$ and $\mathrm{Cd}$, ranging from $0.040 \pm 0.020 \mathrm{mg} / \mathrm{kg}$ to $0.044 \pm 0.001 \mathrm{mg} / \mathrm{kg}$. 
The results of heavy metal concentrations of Clams sold in open markets in Port Harcourt and Yenagoa, as shown in Table 1, revealed that the levels of Chromium were higher in samples collected from Rumuokoro and Mile 1 in Port Harcourt, compared to all the samples procured from Yenagoa that had almost the same range of mean values. Although, there was no significant difference $(p>0.05)$ between mean values of samples collected from both Port Harcourt and Yenagoa, in terms of chromium level. The values of $\mathrm{Cr}$ obtained across the sample sites were below the World Health Organisation permissible limit shown in Table 2 and poses no health risk for consumers. This finding is similar to the observation of [4], that $\mathrm{Cr}$ is a non-essential metal required in small amount for the biological activities of organisms, but is in variance with the findings of [12], who reported of higher concentrations of Cr in Egeria radiata from creeks in Burutu area of Delta state, due to oil pollution. According to [15], higher concentrations of Cr above $5 \mathrm{mg} / \mathrm{kg}$, is capable of causing skin irritation and ulceration in short exposure, and mutation and cell damage for a long exposure.

The obtained results in the present study revealed that $\mathrm{Cd}$ mean values for samples obtained from open markets in Port Harcourt were significantly high compared to the ones procured from markets in Yenagoa. The Cd concentrations in samples obtained across sites in Port Harcourt, were above WHO permissible limits shown in Table 2, while samples obtained across markets in Yenagoa, fell below the WHO standard for human consumption. This findings observed across open markets in Port Harcourt is similar to that of [12] who attributed higher Cd concentrations in fresh water Clams to array of anthropogenic activities like oil and gas exploration. Cadmium as a non-essential micro-nutrient, even in minute form is still toxic and consumption of food with Cd is hazardous to human health [16].

The heavy metal concentrations of Clams sampled from open markets in Port Harcourt and Yenagoa, as shown in Table 1, revealed that samples procured from Port Harcourt had higher levels of Lead (Pb) than those sampled from Yenagoa, with samples from Rumuokoro market (PM2) recording the highest mean value, while samples obtained from Opolo market (YM1) in Yenagoa, had the lowest mean value. The levels of $\mathrm{Pb}$ in samples across the stations were below the standard limits set by W.H.O. Although, Pb is one heavy metal that is toxic with no nutritional value to living organism and no amount of Lead is considered safe for food [17].

\section{Conclusion}

Generally, the results of the study revealed that all the tested heavy metals of Clams were present at varying levels across the sample stations, which is an indication of heavy metals contamination of the aquatic ecosystems in Port Harcourt and Yenagoa areas of Niger Delta. The concentrations of heavy metal were more in samples procured from markets in Port Harcourt than that of samples obtained in Yenagoa, and this could be attributed to dominance of oil and gas exploration, Chemical industries, abattoir, mechanic workshops, pipeline vandalism and other anthropogenic activities in Port Harcourt than Yenagoa. Therefore ,there is need to monitor, assess and evaluate the aquatic ecosystem in Rivers and Bayelsa states routinely, to forestall further heavy metals contaminations in order to reduce the health risks to the barest minimum.

\section{Compliance with ethical standards}

\section{Acknowledgments}

The authors wish to appreciate Dr. B. B. Babatunde of the Animal and Environmental Biology, University of Port Harcourt, Nigeria for his supports during this research work.

\section{Disclosure of conflict of interest}

The authors declare that there was no conflict of interest, the manuscript was sent for publication based on the authors' consent.

\section{References}

[1] Orose E, Odioko E, Wokeh OK. Catalogue of some Saltwater and Freshwater Fish Species of the Niger Delta Region of Nigeria. World.J. Advan. Res. Rev. 2021; 9(3): 56 - 84.

[2] Okey-Wokeh CG, Obunwo CC, Wokeh OK. Evaluation of Water Quality Index Using Physiochemical Characteristics of Ogbor River in Aba, Abia State, Nigeria. J.Appl.Sci. Environ.Manage. 2021; 25(1): 47 - 51.

[3] Hossen MF, Hamda S, Rahman RM. Review on the Risk Assessment of Heavy Metals in Malasian Clams. The Scienti.World. J. 2015; 9(7): 1 - 7. 
[4] Ai YS, Koh HD, Seong WL, Aweng ALE. An Assessment of Heavy Metals Toxicity in Asian Clam, Corbicula fluminea, from Mekong River, Pa Sak River and Lopbari River, Thailand. The Scienti.World J. 2019; 6(1): 1 - 5.

[5] Kinuthia GK, Ngure V, Bati D, Lugalia R, Wangila A, Kamau. Levels of Heavy Metals in Waste Water and Soil Samples from Open Drainage Channels in Nairobi, Kenya: Community Health Implication. Scienti Rep. 2020; 10: 8434, 1-13.

[6] Wasiu MO, Ayodele OE, Ayodele TI, Oluremi OI, Temitope OK, Temitope FO. Heavy Metal Contamination in Stream Water and Sediments of Gold Mining Areas of South Western Nigeria. Afri.J.Environ. Sci.Tech. 2016; 10(5): 150 161.

[7] Huang Z, Liu C, Zhao X, Dong J, Zheng B. Risk Assessment of Heavy Metals in the Surface Sediment at the Drinking Water Source of the Xiangjiang River in South China. Environ. Sci. Europ. 2020; 32(23): 1 - 9.

[8] Nwankwoala HO, Angaya YB. An Evaluation of Heavy Metals Concentration in the Choba Section of the New Calabar River, Eastern Niger Delta. Biodiv.Intl. J. 2017; 1(6): 62 - 68.

[9] Ikeogu CF, Ogbonnaya HF, Okpala-Ezennia KP, Nwankwo CG. Heavy Metal Analysis of Consumer Fish Sold in Three Selected Markets in Awka, Anambra State, Nigeria. Sing. J. Scienti.Res. 2021; 11(1): 17 - 22.

[10] Chepkirui M, Orina PS, Opiyo M, Muendo P, Mbogo K, Omondi R. Fatty Acids Composition of Nile Tilapia (Oreochromis niloticus) Fingerlings Fed Diets Containing Different Levels of Water Spinach (Ipomoea aquatic). J.Agric.Food Res. 2021; 5: 1-8.

[11] Wokeh OK, Woke GN, Orose E, Odioko E. Comparison of Growth Performance of African Catfish (Clarias gariepinus) Fed with Different Standard Feed. Intl. J.Fish. Aquat. Stud.. 2020; 8(5): 394 - 397.

[12] Nwabueze AA. Heavy Metal Concentrations in Tissues of Egeria radiata (Bivalvia tellinacea) from Creeks in Burutu Area of Delta State, Nigeria. Intl .Res.J.Agric.Sci. Soil Sci. 2011; 1(2): 035 - 039.

[13] Kanakaraju D, Ibrahim F, Berseli MN. Comparative Study of Heavy Metal Concentration in Razor Clam (Solen regularis) in Moyan and Serpan, Sarawak. Global J.Environ. Res. 2013; 2(2): 87 - 91.

[14] Okey-Wokeh CG, Obunwo CC, Boisa N. Comparative Air Quality Study of Two Commercial Cities in Southern Nigeria. IOSR J.Appl.Chem. 2020; 13(1): 38 - 44.

[15] Alam H. Toxic Poultry Feed Poses Health Risk. The Daily Star, Bangladesh. 2010.

[16] Ipeaiyeda AR, Onianwa PC. Pollution Effects of Food and Beverages Effluents on the Alaro River in Ibadan, Nigeria. Bull. Chem.Soc.Ethiop. 2011; 25(3): 347-360.

[17] Edokpayi, J. N., Odiyo, J. O., Popoola, O. E. \& Msagati, T. A. M. (2016). Assessment of Trace Metals Contamination of Surface Water and Sediments: A case study of Mundi River, South Africa. MDPI Sustain., 8(135), 1-13. 